\title{
パイル織物における色名および色差の認識
}

\author{
三重県工業技術センター 西 松 豊 典 \\ 東京工業大学 酒井哲也
}

\section{RECOGNIZATION OF COLOR NAME AND COLOR DIFFERENCE ON PILE FABRICS}

\author{
By Toyonori Nishimatsu ${ }^{* 1}$ and Tetsuya Sakai ${ }^{* 2}$ \\ -1 (Department of Textile, Mie Prefectural Industrial Research Institute, \\ Tsu-City, Mie, Japan) \\ -2 (Department of Textile and Polymeric Materials, Tokyo Institute of \\ Technology, O-okayama, Meguro-ku, Tokyo, Japan)
}

This is a paper concerned with investigating and discussing how the specialists' or consumers' groups perceive the color names and color differences of pile fabrics.

The results obtained are as follows.

(1) Specialists assigned most of color names to the colorimetric ones, but those perceived by consumers did not agree well with the colorimetric ones. A long term training for the specialists in the color recognition results in the exact recognition of the surface colors of pile fabrics and in the proper assignments of the color name. On the other hand, consumers do not realize the correct meanings of the tone adjectives for the lack of experience.

(2) The color names perceived by specialists and consumers by the use of the standard color chips corresponded well to the colorimetric ones.

(3) The correlation coefficient between the color differences perceived by specialists and the colorimetric ones was very high, but the coefficient for the consumers' was low. This fact also indicates as that specialists have established the standard colors for the judgement of color differences by a long term experience on the color differences.

(Received July 18, 1985)

\section{1. 堵言}

JIS Z8102「色名」では，系統色名的な报いの一般 色名上，固有色名的な扱いの慣用色名加規定されている。 一般色名は10種類のマンセル色相名である基本色名に 明度およで彩度に関する修飾語，色相に関する修飾語を 付けて体采的任㭔ぶ方法が定められているが，固有色名 は個人の色彩経験に基づく記憶色イメージの伝達である ので体系化されていない。こで，体系化されている一 般色名について問題になるのは測色徝に基ついて表示さ

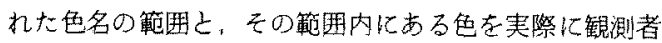
が見て認識する色名とでは，色名に差が生じないかとい
うととである。さらに，観測者の色彩経験によっても色 名に対する喼識が異なることも予测される。また，同一 色でも背景色の影響によって異なった色儿知筧するてと が多々経験さ机る。この知覚される色名の相違は，背兒 色の影響によって生じる色差の大小をどの程度知賞して 色名上して珰識するかというととである。

このような状況に対し，専門家あるいは非専門家を゚ ネルとし，ある色票について知覚される色差と浿上の 色差との対応関係ならびに色名から感じられる色の笽用 を考察した研究は数多くみられる”が，対象を䋘物比し た研究ははと儿よ゙影告されていない。 色票を用いて色差扰上び色名判定を行う場合，色票り 
表面には大きな凸凸がないので，染色された色票につい

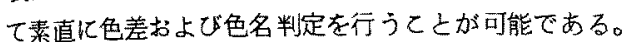
しかし，パイル織物を対象として色差および色名判定を 行う場合，色票の場合と異なり染色されれたパイル織物の 表面色がパイル系のパイル形状止よびタテ系・ヨコ系・ パイル系の交錯状態によって形成される複雑な几几状態 によって，実際の染料色とは微妙に異なる色求よび色差 を人間の視覚に与えると考えられる。

また，パイル織物について色名および色差判定経験を 積み重㸚ることによって、織物の測色色名および色差と パネルが知賞した色名术よび色差間の差異の大小が在右 されるととも予測される。

そこで，本研究では片面に力ラ一芯地を接着したパイ 儿䌐物を試料として取り上げ，専門家および消費者グル ープに提示して知覚した色名拉よび色差と測色值に基づ く色名および色差との差異を比較検討した。

\section{2. 試料および実験方法}

\section{1 表色実禹}

パイル織物の片面にカラー芯地を接着条件温度 $140^{\circ} \mathrm{C}$, 印力 $250 \mathrm{~g} / \mathrm{cm}^{2}$ で接着し織物武料とした。芯地には有彩 色12色および無彩色7色を選んだ。こてで，有彩色芯 地12色はアパレル素材用パイル織物の接着芯地として 使用さ扎ている代表的な力ラーである。

そして，307 型日立カラーアナライザを用いて各試料 のXYZ3 刺激值, $x y$ 色度座標索測定し, JIS $Z 8721 \mathrm{~K}$ したがい $x, y, Y$ 值から色知覚の 3 属性(色相, 明度。

彩度)を求めた。その結果を表1亿示す。なお，試料の 大きさは $40 \times 40 \mathrm{~mm}$ である。

JIS Z 8102 亿基づく色名表示方法は，消費者グルー プから難解である上評価されたので，数多くの色彩調查 に使用されている調查用カラーコード(日本色彩研究所

Table 1 Test color chips.

(a) Chromatic color (b) Achromatic color

\begin{tabular}{|c|c|c|c|}
\hline Chip No. & $\mathrm{HV} / \mathrm{C}$ & Chip No. & V \\
\hline 5 & $\begin{array}{ll}0.1 \mathrm{R} & 3.3 / 3.8\end{array}$ & 1 & 9.2 \\
\hline 8 & 3.7 YR $3.2 / 1.6$ & 2 & 9.1 \\
\hline 25 & 2.5 PB $8.7 / 1.9$ & 21 & 4.6 \\
\hline 28 & $2.0 \mathrm{R} \quad 3.8 / 9.3$ & 27 & 2.5 \\
\hline 39 & 6.8 PB $3.2 / 6.2$ & 40 & 2.7 \\
\hline 43 & $1.4 \mathrm{G} \quad 8.3 / 1.7$ & 46 & 8.5 \\
\hline 44 & 8.4 PB $7.6 / 4.2$ & 47 & 7.0 \\
\hline $\begin{array}{l}45 \\
51\end{array}$ & $10.0 \mathrm{Y} \quad 9.0 / 1.3$ & & \\
\hline 53 & $\begin{array}{l}1.5 \mathrm{YR} 7.0 / 2.3 \\
10.0 \mathrm{GY} 6.0 / 2.3\end{array}$ & & \\
\hline 54 & $5.0 \mathrm{~B} \quad 7.1 / 4.0$ & & \\
\hline 72 & 4.0 RP $8.3 / 3.2$ & & \\
\hline
\end{tabular}

Where $H$ is the, $V$ is value, and $C$ is chroma.
編) 光活用した。

各種の色名は，(1)トーンの形容詞书よび色みの形容 詞，（2）イメージ連想語，（3）基本的色名，の3 つの用

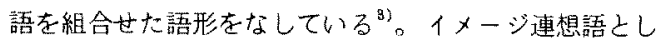
ては主に固有色名汃用いられ，基本的色名にトーンの形 容詞拉よび色みの形容詞を組合せた色名が系統色名に相 当するが，調査用カラーコードはこの系統色名をJISの 場合上り平易な用語で 230 㮔に分類している。そして。 トーンの形容詞は 12 種類，色みの形容詞は 8 種類，基本 的色名は 10 㮔類のマンセル色相名にピンク，ブラウン、才 リーブを加えた13 種類である。なお，本研究では各采統 色名の整理を簡単にするため纪みの形容詞之基本的色 名とを組合甘た色名を基本的色名とよふととにする。表 2 (a), (b)はトーンの形容詞书上び色みの形容詞を示す。 色名に関寸る調查用紙の形式は、トーンの形容詞书よ び基本的色名を示したものであり，有堁色試料について の実験方法はつぎのとおりである。

（1）まず基本的色名について各純色色票を提示して説 明を行った。以後ての説明行為を予備学習とよぶてとに する。その後，バネルに調菒用紙を渡して12 種類の織 物試料をランダムに提示し，色名を表示させた。パネル は消責者】グループ(10名)である。

（2）基本的色名以ついて予備学習を与えず代，調查用

Table 2 Tone adjective, hue adjective and achromatic color name.

(a) Tone adjective

pale ... deep

light ... deep

bright .... dark

vivid .... grayish

light grayish ... - dark grayish

strong

soft

dull

(b) Hue adjective

reddish

yellowish

greenish

bluish

purplish

pinkish

brownish

olive

(c) Achromatic color name

white

very light gray

light gray

gray

dark gray

very dark gray

black 
䋏を渡してランダムに織物試料党提示して，試料の色名 表表現させた。パネルは消費者【グループ(10名)および 専門家グループである。

（3）「色の標隼」色票 ${ }^{4}$ を提示して織物試料と比較検 討させ，各試料の色相，明度，彩度を表示させた。パ六 ルは消費者】ー】グループおよご専門家グループである。 無堁色試料については，表2（c）に示色色，ならび に上記(3)の方法で各試料の色名在，消費者 1・【グル 一プおよび専門家グループに表示させた。

以上の表色害験は約 $10001 \times 0$ 照度下でN8 背景に して行い，照明拉よび観察条件はJIS 28723 (表面色の 比較方法)に準拠している。な怙，専門家グループはブ ザイナー 5 名( $35 \sim 45$ 才の色覚正常者)，消費者 I：II グ ループは衣料学を専攻する女子短大生(19〜20才の色覚 正常者)である。

\section{2 色美認識に関する実験}

微少な色差の認識程度は，パネルの争に対する学習 経験によって差が生じるよ考えられる。衣料品ではしば しば色の異なったものを重构て使用し，その際生しる微 妙な色差が装飾効果として利用される。このような意味 を踏去元、以下の実験を試みた。

白色背景 (N8)，黒色背景(N3) の上に闰色の織物試 料を図 1 亿示すように並べた試験色差対を提示し，知覚 される色差感賞の大小をつぎのような 5 段階評価法在用 いて消費者および専門家グループに目視で判断させた。

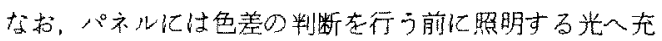
分順态させ，また判定時間は制限せず観測させた。

$\begin{array}{lr}\text { 色の差がほとんど認められない。（語点） } & +1 \\ \text { 色の差がわずかに認められる。 } & +2 \\ \text { 色の差が相当に認められる。 } & +3 \\ \text { 色の差が著しい。 } & +4 \\ \text { 色の差がきわかて著しい。 } & +5\end{array}$

Test pair

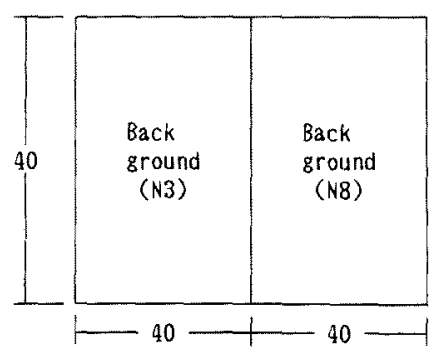

$B a c k$ ground (N 8)

Fig. 1 Color difference pair.
実験は晴天時の北空昼光下 (奏験時の平均照度 $1000 \mathrm{~lx}$ ) において行った。なお，夷験に用いた試料は表 1 に示す 有黗色 12 色，無彩色 6 色であり，専門家グループは色 差検查㐾事者 4 名(経験年数 5 年以上)，消費者グループ は农料学を專攻する女子短大生 10 名である。

\section{3. 実験結果および考察}

\section{1 測色上の色名上知覚される色名しの刘広}

基本的色名について予備学習学行った消費者 Iダルー プ，予備学習を行わない消費者 II グループおよび専門家 グループ，各々が色名判定した結果を比較するとつぎの ようになる。

調查用紙の回答経過時間について，消費者 Iグループ は 1 試料 1 人当り平均 30 秒，消費者II゙ループは 48 秒， 專門家グループは32 秒であった。消費者 Iグループと専 阴家は回答時間が近似しているけれども，消費者品グル ープは消費者 1 グループと此較すると 1.6 倍長く回答時 間が経過している。

専門家は測色色名亡知覚色名の対応関係を反復学習比 より，それぞれの色刺激に対応する知覚色名を複雑圾袖 経細胞の連鎖が作る闒回路 ${ }^{5}$ に記憶する。そして、長期 間種々の色刺激老繰り返し受容することによって，閉回

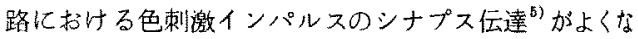
るので回答時間が速くなるのであるう。

消費者】・II゙ループ間におけるトーンの形容詞书よ 己゙基本的色名の一致率はそ机ぞれ 50.0，76.7\%であった。 消費者」グループよ専門家グループについて，各一致率 はそれぞれ 47.2，77.8\%であった。消費者】グループと尃 門家グループにつて，各一致率はそれぞれ 48.3，86.1 \%であった。

なお，トーンの形容詞扰よび基本的色名の一致率はつ ぎのようにして求めた。2つのグループのパネルが知賞 した形容詞名および基本的色名上测色された形容詞名お よび基本的色名乞をそれぞれ比較して，測色值と一致し たパネルの人数を面グループの総パネル数で割ったすの である。

各グループ間の基本的魚名の一致率は比較的高い值を 示し，加つ大きな差がみられないのて，基本的色名関 しては予備学習の效果が少ないと考えられる。乙れ怙 消費者绝色彩環境・経験に上って，基本的色名汇関する 予備知識が潜在的にある程度具備されているからでる j。

一方、トーンの形容詞の一致率が低いのは（1）トー ンの形容詞が明度扰よび柇度を組合せて構成されている ので，2 属性(明度，彩度)とトーンの形容詞との対応関 䋆が体系化されていない消費者に原因があるの加，てれ 
とも(2)消費者がトーンの形容詞の意昧を正確に認識し ていないため，測色されたトーンの形容詞と知賞した形 容詞間に言䈎のズレが生じているのか、そのどちらかが 原因であろう。

そこで，消費者および専門家グループが知覚した有彩 色名执よび湘色色名をカラーチャート上にプロットし， その一部を図 2 に示す。なお，カラーチャートは26 種の 各等色相面において修正マンセルシステムの明度・彩度 を経緯とする座標上に，各色名ブロックの範用の区画を 定めた色彩地区である。このカラーチャートにプロット するととにより、知覚したトーンの形容詞か測色した形 容詞とどの程度差異があるか不確憶できる。

图2に示されるように、試料No. 53 は light grayish greenであり，専門家の判定よ一致しているが，消費者 はdull green, dark green, dark grayish green. light yellowish green, soft green $亡$ 判定し, 分散し ている。

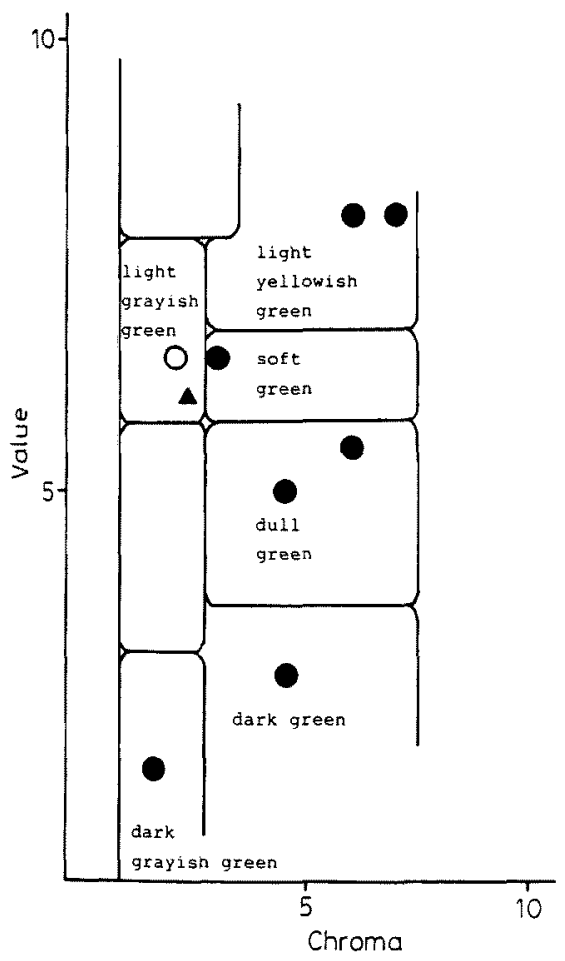

Fig. 2 Relation between colorimetric color names and perceived ones by consumer and specialist groups on color chip No. 53 .

A ; colorimetric name,

- perceived name by consumer, $O$; perceived name by specialist.
カラーチャート上にプロットした結果より，パネルの 知覚色名がどの程度明度，彩度に影響されるかにつて まこめたものか表了である。表 3 において，Lは表面色 より明度あるいは堁度を低く判定しているとと，Hは高 く判定しているととを示し，数字はグループ内において 判定した人数の割合(が)である。例えば，試料No. 5 に ついて消㙖者グループでは測定された表面色より低明度・ 低彩度に判定するパネルがグループ内で $50 \%$ ，高明度・ 高夥度に判定するパネルが $30 \%$ ，低明度・高彩度に判定 するパホルが20\%ということである。

表 3 より，暖色系試料について消費者は表面色より， 低明度・低彩度，低明度・高彩度，高明度・高彩度に判 定し，尃門家は低明度・高彩度に知覚する傾向がみられ た。寒色系，緑系拉よび黄緑系試料について，消費者は 表面色より低明度・高彩度に判定する傾问がるんるが， 專門家は測色色名亡知覚色名との間によい一致がみられ た。

ここで，専門家が知覚した色名と测色色名間によい一 致がみられたのは，明度および彩度を悢合せて構成され たトーンの形容詞を正確に明度执上び移度の大小の組合 せにより認識しているてとに起因している。このてとは，

Table 3 Value and chroma differences between colorimetric colors and received ones by consumers and specialists on the warm and cold colors and the other colors.

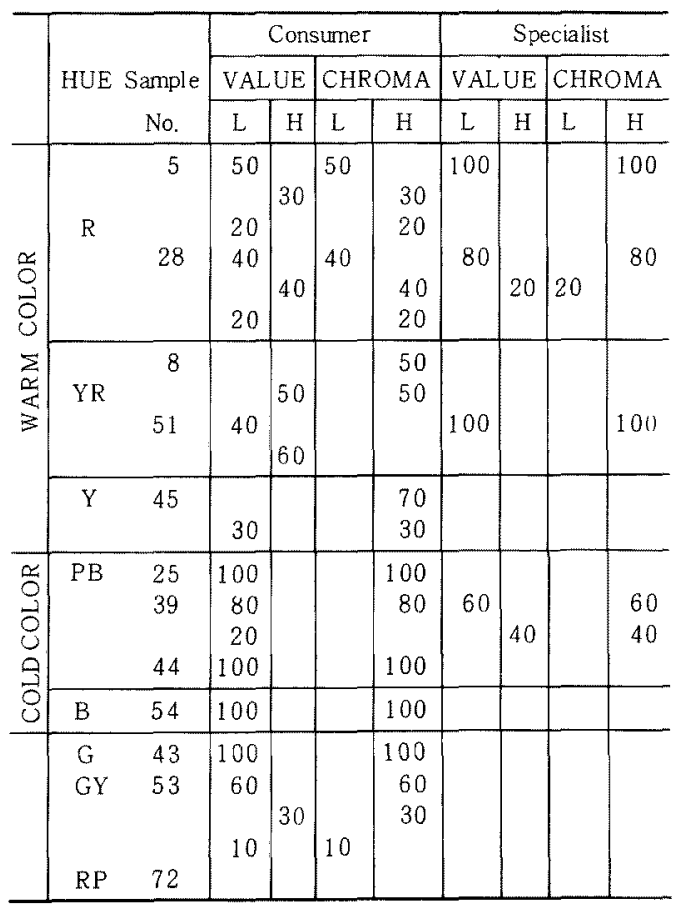


専門家との面接によって確認され，たとえばトーンの形 容詞「あかるい」は明度が高い場合，彩度が高い場合， あるいは洞者が高い場合に採用されるとしている。

一方，消告者についてはトーンの形容詞の不一致の原 因を明らかにするため，つぎのような第2 回表色奏験を 行った。すなわら，実際に测定されたトーンの形容詞で 表色された色票上消費者が第 1 回表色奏験で知覚したト ーンの形容詞で表色された色票とを消貲者に提示して， 耐者を比較させるとともに，測定されたトーンの形容詞 で表色されるべき色票を選び出させた。表4は，各試料 について湖定された形容詞，最初の表色奏験で消費者が 知賞したトーンの形容詞，第 2 回表色奏験で得たトーン の形容詞の結果を示す。

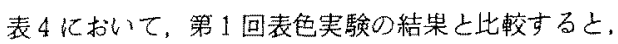
第 2 回表色実験で知覚したトーンの形容詞と測定された トーンの形容詞とはよい一致がみられる。これは，消費 者が実際に色知賞していたトーンの形容詞と消費者自身 が言葉として記憶していたトーンの形容詞間に形容詞の 認識のズレが存在しているととを示している。すなわち， 消費者はトーンの䚹容詞の意眜内容を正確に認識してい ないため、織物試料について知覚した色名を適確に表現 できないということが明らかになった。

つぎに，消費者および専䣙家グループに系統色名によ
つて色彩分類された「色の標準」色票と各織物武料とを 対照させて，色名を判定させた結果を表 5 に示す。 無彩色試料についても同様にして，「色の標準」色票 により色名を画パネルグループに判定させ，その結果を 表6に示す。また，表2（b）に示す無彩色名で回答させ た結果む併せて示した。

表 5 および表6に示されるように，両パネルグループ 上屯「色の標準」色票上対照して選択した色名は測色色 名よよく一致していた。このように有彩色执よび無彩色 試料において，基準となる「色の標準」色票を与えられ ると、パネルは色彩経験之無関係比試料と標準色票を比 較対照するだけなので，消費者ですら測色色名とよい 致がみられるのであろう。これは，人間の視覚機能にお いて色を単純儿比較する機能が学習経験時間とは無関係 に優れているととを示唆しているのであるう。

一方，パネルが無彩色試料の表面色を色覚してその色 名言葉で表現する場合については，試料No．27，460 知覚色名と測色色名とが両パネルグループとも異なって いる。とれは，図3に示されるように試料No.27はblack, 試料No. 46 は light grayの範囲に近く位置しているの で，消費者・尃門家ともそれぞれ測色色名 dark gray， white 亡識別できないからである。このように，色名の 境界に位置する色を見て言葉で色名を連想する場合，専

Table 4 Relation between the received tone adjectives by the consumer group before and after studying the tone adjectives.

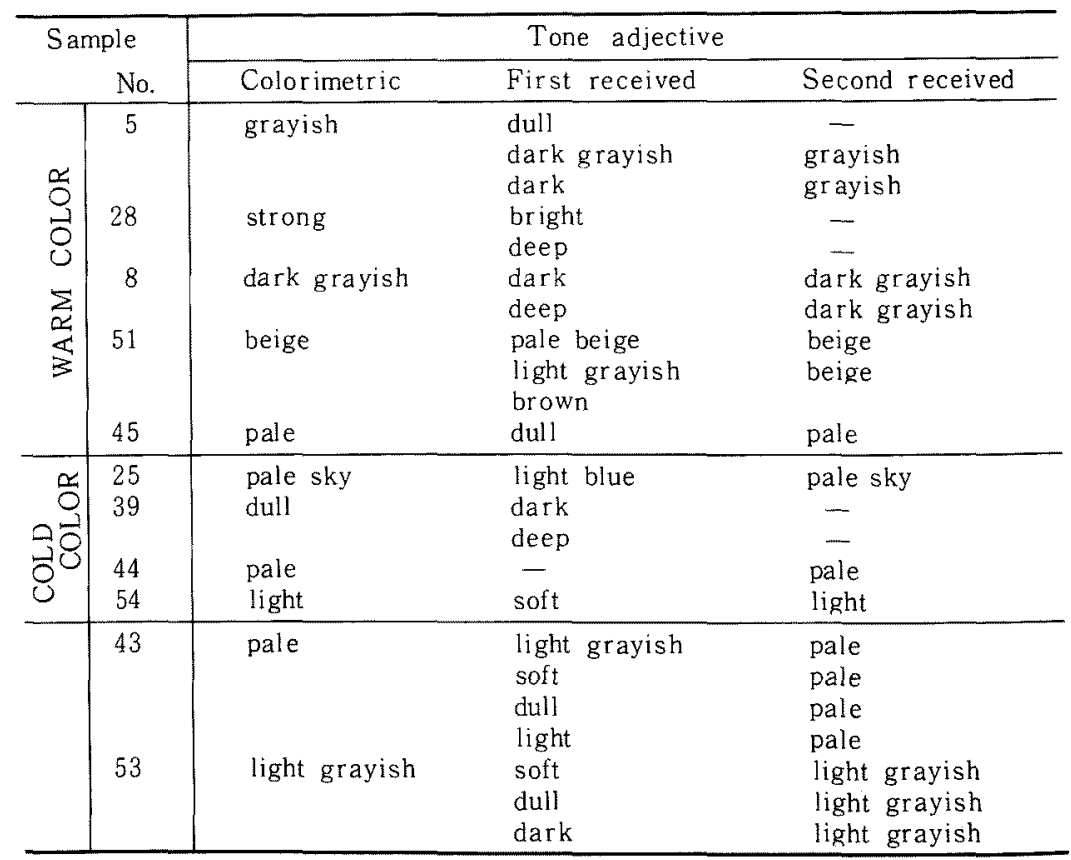


Table 5 Comparison between colorimetric color names and received ones.

\begin{tabular}{|c|c|c|c|}
\hline Chip No. & Colorimetric name & $\begin{array}{l}\text { Received name by } \\
\text { consumer }\end{array}$ & $\begin{array}{l}\text { Received name by } \\
\text { specialist }\end{array}$ \\
\hline $\begin{array}{l}5 \\
8\end{array}$ & $\begin{array}{l}\text { grayish red } \\
\text { dark grayish brown }\end{array}$ & $\begin{array}{l}\text { * grayish red } \\
\text { * dark grayish brown } \\
\text { dark reddish gray }\end{array}$ & $\begin{array}{l}\text { * grayish red } \\
\text { * dark grayish brown }\end{array}$ \\
\hline 25 & pale sky & * pale sky & * pale sky \\
\hline 28 & strong purplish red & $\begin{array}{l}\text { dark red } \\
\text { dull red }\end{array}$ & * strong purplish red \\
\hline 39 & dull purplish blue & * dull purplish blue & * dull purplish blue \\
\hline 43 & pale yellow green & pale bluish green & pale bluish green \\
\hline 44 & pale lavender & lavender & * pale lavender \\
\hline 45 & yellowish white & * yellowish white & * yellowish white \\
\hline 51 & be ige & pinkish be ige & - beign \\
\hline 53 & light grayish green & $\begin{array}{l}\text { * light grayish } \\
\text { green }\end{array}$ & $\begin{array}{l}\text { * light grayish } \\
\text { green }\end{array}$ \\
\hline 54 & light greenish blue & $\begin{array}{l}\text { * light greenish } \\
\text { blue }\end{array}$ & $\begin{array}{l}* \text { light greenish } \\
\text { blue }\end{array}$ \\
\hline 72 & pale purplish pink & $\begin{array}{l}\text { pale yellowish } \\
\text { pink }\end{array}$ & * pale purplish pink \\
\hline
\end{tabular}

Table 6 Comparison between colorimetric color names and received ones by word method and standard color method.

\begin{tabular}{|c|c|c|c|c|c|}
\hline \multirow[t]{2}{*}{ Chip No. } & \multirow{2}{*}{$\begin{array}{l}\text { Color imetric } \\
\text { color name }\end{array}$} & \multicolumn{2}{|c|}{ Color name by consumer } & \multicolumn{2}{|c|}{ Color name by specialist } \\
\hline & & Word & $\begin{array}{l}\text { Standard } \\
\text { color }\end{array}$ & Word & $\begin{array}{l}\text { Standard } \\
\text { color }\end{array}$ \\
\hline 1 & white & white & white & white & white \\
\hline 2 & white & white & white & white & white \\
\hline 21 & medium gray & medium gray & medium gray & medium gray & medium gray \\
\hline 27 & dark gray & black & dark gray & black & dark gray \\
\hline 40 & dark gray & $\begin{array}{l}\text { very dark } \\
\text { gray }\end{array}$ & dark gray & $\begin{array}{l}\text { very dark } \\
\text { gray }\end{array}$ & dark gray \\
\hline 46 & white & $\begin{array}{l}\text { very light } \\
\text { gray }\end{array}$ & white & $\begin{array}{l}\text { very light } \\
\text { gray }\end{array}$ & white \\
\hline 47 & light gray & light gray & light gray & light gray & light gray \\
\hline
\end{tabular}

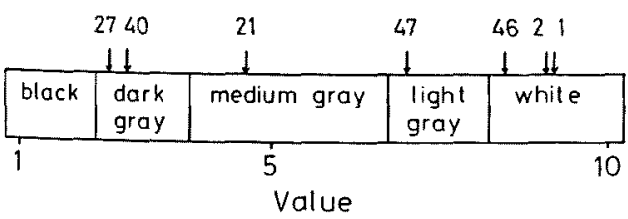

Fig. 3 Relation between perceived color names by consumer and specialist groups and colorimetric ones of achromatic color chips on the color chart.

闍家ですら物体色より明度を低くして色覚する䝨向がみ られた。

\section{2 測色上の色差と知賞される色差との对応}

現在、CIE(国際照明委員会)は $1976 L^{*} u^{*} v^{*}$ 之 1976 $L^{*} a^{*} b^{*}$ の均等色空間およびそれぞれに対応した色差式 を勧告し、JIS 28730 (色差表示方法) に採用されてい
る。CIE1976 L $L^{*} a^{*} b^{*}$ 空闒上その色差式は，䋐維工業て 取り扱狆るような小色差の問題に応用されているので， 本実験では己れを用いた。1976 $L^{*} a^{*} b^{*}$ 空間こその色差 式は次式で定義される量で表わされる。

$$
\begin{aligned}
& L^{*}=116\left(Y / Y_{n}\right)^{1 / 9}-16 \\
& a^{*}=500\left[\left(X / X_{n}\right)^{1 / 3}-\left(Y / Y_{n}\right)^{1 / 3}\right] \\
& b^{*}=200\left[\left(Y / Y_{n}\right)^{1 / 3}-\left(Z / Z_{n}\right)^{1 / 3}\right]
\end{aligned}
$$

ただし， $X, Y ， Z$; 対象とする物体の 3 刺激値

$X_{n}, Y_{n}, Z_{n}$ ；照明に用いた標準光の 3 刺激值 それぞれ $L^{*} a^{*} b^{*}$ で屯って与えられる2色間の色差は次 式で求められる。

$$
\Delta E^{*}{ }_{a b}=\left[\left(\Delta L^{*}\right)^{2}+\left(\Delta a^{*}\right)^{2}+\left(\Delta b^{*}\right)^{2}\right]^{1 / 2}
$$

表 7 は各試験色羑対について測色上の色差を示す。専 門家・消費者グループが各試験色差対について色差の見 え方の大小を 5 段階評価した評定値を次式によって変換 
Table 7 Colorimetric color difference $\left(\Delta E^{*}{ }_{a b}\right)$.

\begin{tabular}{c|c|c|c|c|c}
\hline Chip No. & $\Delta E_{a b}^{*}$ & Chip No. & $\Delta E_{a b}^{*}$ & Chip No. & $\Delta E_{a b}^{*}$ \\
\hline 5 & 0.58 & 44 & 1.57 & 1 & 1.88 \\
8 & 0.34 & 45 & 1.86 & 2 & 1.40 \\
25 & 1.80 & 51 & 1.22 & 21 & 0.81 \\
28 & 1.15 & 53 & 1.01 & 27 & 0.52 \\
39 & 0.66 & 54 & 1.46 & 40 & 0.24 \\
43 & 1.71 & 72 & 1.52 & 46 & 1.38 \\
\hline
\end{tabular}

Table 8 Comparison between standard deviations of $P$ received by the consumer group and ones by the specialist group.

\begin{tabular}{c|c|c}
\hline Chip No. & Consumer & Specialist \\
\hline 5 & 0.52 & 0.27 \\
8 & 0.67 & 0.28 \\
25 & 0.52 & 0.27 \\
28 & 0.82 & 0.31 \\
39 & 0.67 & 0.32 \\
43 & 0.88 & 0.40 \\
44 & 0.67 & 0.11 \\
45 & 0.82 & 0.37 \\
51 & 1.20 & 0.35 \\
\hline
\end{tabular}

\begin{tabular}{c|c|c}
\hline Chip No. & Consumer & Specialist \\
\hline 53 & 1.06 & 0.45 \\
54 & 0.82 & 0.23 \\
72 & 0.48 & 0.37 \\
1 & 0.67 & 0.30 \\
2 & 1.06 & 0.25 \\
21 & 0.95 & 0.10 \\
27 & 0.84 & 0.21 \\
40 & 0.70 & 0.11 \\
46 & 0.57 & 0.28 \\
\hline
\end{tabular}

し，その值を知覚される色差 $\left(\Delta E_{p}\right)$ と定䉝する。

$$
\Delta E_{p}=\Delta E_{a b}^{*} \cdot P
$$

ただし， $P$ ；各試験色差対に与えられた評定值

ここで，両パネルグループが各試験色差対について評 洒した評定值Pのバラッキ程度を考察するために，Pの 標隼偏差ををれぞれ求め，その結果を表 8 亿示す。各試 験色差対について尃門家グループよ消費者グループの結 果老各々此較すると，専門家グループの標集偏差が消費 者グループの結果より小さいので，尃腚グループ内の

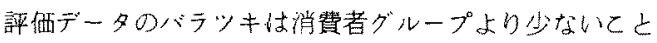
がわかった。

汹 4 は， $L^{*} a^{*} b^{*}$ 空間に打ける各試験色差対について 测色上の色差 $\Delta E^{*}{ }_{a b}$ K詨古る知覚される色差の平均値 $\overline{\Delta E_{p}}$ の関係を示したあのである。回帰直線の傾きの大小 はハホネルの刍に対する感度の大小を示している。よっ て，専閸は色差に対して非常に感度が高く正確に知覚 しているが，消蛽者は個人差が大きく色差に対する知覚 感度が低いししがかかる。

平井ら ${ }^{81}$ の実験によれ代，色差加認められるか否かの 判断基準で色比較を行うと， $\Delta E^{*}{ }_{a b}$ が 0.3 メ内であるよ 差なしと判断される確率は高いけれど，0.3在越え 1.3 に 至る間は判断に瞹昧さを伴う。とくに，0.4 0.60色差 值を有する色対の比較では五分五分の評洒であり，色差 値が 1.3 を越えると誰でるが色差ありと評価すると報告 している。

そこで，各試験色差対について測色上の色差 $\Delta E^{*}{ }_{a b}$ 上

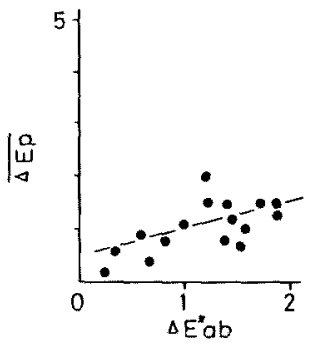

(a)

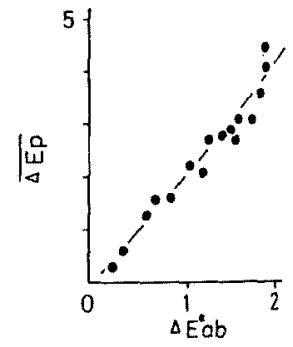

(b)
Fig. 4 Comparison between colorimetric color differences $\left(\Delta E^{*}{ }_{a b}\right)$ and perceived ones by consumer and specialist groups $\left(\overline{\Delta E_{p}}\right)$; (a) consumer group, (b) specialist group.

色美が認められるか否かの確率 $R$ 上の対応関係を图 5 亿 示す。図 5 において，R=100\%の上きは誰でもが色差は しと評洒するということである。図5に示されるように 一部の点を除いて専門家は色差 $\Delta E^{*}{ }_{a b}$ 少 0.8 を越えると 色善あり之誰でもが認識するけれども，消責者について は誰でもが色差ありと評価する色差值 1.3 を越えても判 断に曖味さを伴って招り，平抹らの結果とは異なってい る。また，専門家は色差值 0.5 以内であると差なしと判 断する確率は高く，色差が認められるか否加の判断漕 味さを伴う色差範用は小さい。しかし，本実験の色差笔 囲においては，消費者について色差加認められるか否か の判断に全体的に瞹味さが認かられた。

とのように本実験の結果と平井らの実験結果とが異な 


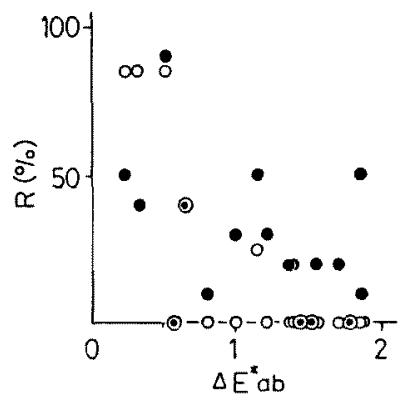

Fig. 5 Relation between colorimetric color differences $\left(\Delta E_{a b}^{*}\right)$ and perceived one percents $\langle R\rangle$, - ; consumer, $O$; specialist.

るのは，平井らの実験が陚料に織物ではなく色票を用い て行わ机ていることに原因があると考えられる。 以上の結果上り，専門家は日常色差判定試験敒従事す るととによって，知覚される色差に対して測色上の色差 を対応させる学習を反復するととにより，個人差をなく した色差判断基準の細分化を確立して色差を適確に評価 することができるのであるう。一方，消費者は各個人の 色差経駼飞基ついた大まかな色差判断基準段階により色 差評価在行っているので，色差に対する個人差が大きく、 その判断曖味になると考えられる。すなわち，専門家 上消費者による色差評価結果の相違は，学習経験期間の 長短任基つく色差判断基準の細分化の度合に上るもので あろう。いずれにせよ，との点について上り詳細な議論 を行うためにはさらに史験を重极る必要がある。

\section{4. 結諞}

煿門家および消費者グループにカラー芯地接着パイル 織物を提示して，知覚された色名や色差上測色上の色名 や色差との対応関係考蔡し，つぎのような結果が得ら 枕。

（1）専門家によって知賞される有彩色名は測色上の色 名とよい対応関係汃みられた。乙れは，尃閶家加長期的
な色影学習によって各物体色認識し，それそれれを色彩 分類して適切な色名に対応寸る関係を神経細胞連銷によ る閉回路に記憶しているからであるう。一方，消費者に 沶いて測色色名上知覚色名上の対応関保がよくないのは， 消費者がトーンの形容詞の意味内容を正確に認識してい ないととに起因している。

（2）基準となる標準色票を用いて織物の色名(有彩色 名・無影色名)を尃閃家および消贊者グループに表現さ 世た場合，而グループとも知覚される色名と実測色名間 にはよい一政がみられた。これは，人間の視覚機能にお いて色を単純に此較認識する機能か，学習経験上は無関 倸で非常に優れていることを示している。

（3）専門家は色差に対して非常に感度加高く正確に知 覚しているが，消費者は個人差が大きく色差に対する知 賞感度加低い。これは，専門家が色差化関する長期的学 習によって，色差に対する知覚感度を高揚するととあに， 個人差加なく細分化された色差判断基準を確立している ためと推測される。

付記：カラー芯地を提供された旭ピカルディ株式会社， ならびに官能検査に協力していただいだ重短期大学川 田光子教授に梁謝いたします。

\section{女献}

1）例えば，塚田 敢、湊 幸衛，野口尚孝，千葉大学 研究報告，19，107（1968）

池田絋一, 中山晶春, 小原清成, 色彩学会，3，12 (1978)

平帅敏夫，色彩研究，27，2(1980)

小松原 壬，平井敏夫，島 善一郎，色影研究， 29, 13(1982)

2) 日本色彩研究所編。「調査用カラーコード(改訂版)」。 日本色研事業(株) (1971)

3) 細野尚志, 色彩研究，18，28 (1971)

4) 日本色彩研究所編。「色の標準」。日本色影社(1951)

5) 時実利应、「脳の話」,岩波新書 高木貞敬，「記憶のメカ二ズム」，岩波新書(1976)

6）平井敏夫，小松原 仕，照学全大予稿集，p. 58 (1978) 